\title{
A validation of Hemo_Vet, a portable hemoglobinometer, in dogs
}

\section{Validação do hemoglobinômetro portátil Hemo_Vet em cães}

\author{
Ana Carolina Pereira'; ${ }^{1}$ Thiago Guerreiro Teixeira ${ }^{2}$; \\ Vanessa Andrea Pincelli³; Mariana Menezes Bochio ${ }^{3}$; \\ Karina Keller Marques da Costa Flaiban ${ }^{4}$; Patrícia Mendes Pereira ${ }^{5 *}$
}

\begin{abstract}
Determinations of hemoglobin $(\mathrm{Hb})$ levels and packed cell volumes (PCV) can be performed by various methods, including rapid testing using a portable hemoglobinometer. As a simple method that requires small blood samples and provides results in seconds, the utilization of portable hemoglobinometers has become increasingly widespread. The aim of this study was to evaluate the performance of the Hemo Vet, a portable hemoglobinometer, in $\mathrm{Hb}$ measurements and PCV determinations in dogs. A total of 100 blood samples were used to compare the $\mathrm{Hb}$ and PCV values provided by the Hemo_Vet with those obtained using an automatic hematology analyzer (BC2800VET) and the microhematocrit technique. The Bland-Altman method was used for data analysis. Bland-Altman analysis revealed a high level of agreement between the $\mathrm{Hb}$ values obtained from the BC2800VET and those obtained using the Hemo Vet. The bias was close to zero (0.17), and although it was statistically significant $(p=0.0003)$, it unlikely would result in any clinically significant effects. The differences in the PCV values generated using the hemoglobinometer and the BC2800VET technique and those generated using the hemoglobinometer and microhematocrit technique exhibited a bias of 7.80 and 2.80, respectively, indicating a high degree of variability between these methods. In addition, the hemoglobinometer was not able to determine PCV values below $18 \%$ and above $59 \%$. The precision, standard deviation and coefficients of variation for the device all showed low variation. These results indicate that the hemoglobinometer exhibits good precision and fulfills its primary purpose, which is to measure $\mathrm{Hb}$ levels. However, this device was less effective in determining PCV values, where it exhibited high level of variation in both methods of comparison. These results revealed the need to change the conversion factor for estimations of PCV values from 2.94 to 3.54 for dogs.
\end{abstract}

Key words: Dog, hemoglobin, hemoglobinometer, packed cell volume

\section{Resumo}

A determinação da hemoglobina $(\mathrm{Hb})$ e do volume globular $(\mathrm{VG})$ de cães pode ser realizada por diferentes métodos, dentre eles o teste rápido pelo hemoglobinômetro portátil. Por ser um método simples, que requer pouco volume de sangue, este método tem se tornado cada vez mais difundido. $\mathrm{O}$ objetivo deste trabalho foi avaliar o desempenho do hemoglobinômetro portátil Hemo_Vet na dosagem de hemoglobina e estimativa do volume globular de cães.Foram utilizadas 100 amostras de sangue de cães comparando os valores de $\mathrm{Hb}$ e VG fornecidos pelo Hemo_Vet com os valores determinados por

1 Residente em Cirurgia de Pequenos Animais pela Universidade Estadual de Londrina,UEL, Londrina, PR. Brasil. E-mail: anacarolina-p@hotmail.com

2 Residente em Cirurgia de Pequenos Animais pela Universidade de Franca, UNIFRAN, Franca, SP, Brasil. E-mail: thiguerreiro@ hotmail.com

3 Mestres em Ciência Animal, UEL, Londrina, PR, Brasil. E-mail: vapincelli@hotmail.com; marianabochio@hotmail.com

${ }^{4}$ Prof $^{a} \operatorname{Dr}^{a}$ do Dept ${ }^{\circ}$ de Medicina Veterinária Preventiva, UEL, Londrina, PR, Brasil. E-mail: kkflaiban@uel.br

Prof ${ }^{\mathrm{a}} \mathrm{Dr}^{\mathrm{a}}$ do Dept ${ }^{\mathrm{j}}$ de Clínicas Veterinárias, UEL, Londrina, PR, Brasil. E-mail: pmendes@uel.br

Author for correspondence 
analisador automático hematológico (BC2800VET) e pela técnica do microematócrito. Para análise dos dados foi utilizada a metodologia de Bland-Altman. Ao comparar os valores de $\mathrm{Hb}$ obtidos pelo aparelho BC2800VET com os valores obtidos pelo Hemo_Vet através do gráfico de Bland-Altman, observou-se alta concordância entre os métodos, com um viés muito próximo de zero $(0,17)$, e que apesar de ser estatisticamente significativo ( $\mathrm{p}=0,0003$ ), não tem importância clínica. Na avaliação da concordância entre o Hemo_Vet e o aparelho BC2800VET e entre o Hemo_Vet e a técnica do microematócrito na estimativa do VG, o viés obtido foi 7,8 e 2,8 respectivamente, indicando grande variação entre os métodos. Além disso, o hemoglobinômetro não foi capaz de determinar valores de VG abaixo de $18 \%$ e acima de 59\%. Na avaliação da precisão do aparelho, os desvios-padrão e coeficientes de variação indicaram pouca variação.. Os resultados obtidos indicam que o hemoglobinômetro portátil Hemo_Vet possui boa precisão e cumpre o seu principal propósito, que é a dosagem de Hb. Já para a estimativa do VG, não se mostrou muito eficaz, por apresentar grande variação em relação aos dois métodos a que foi comparado. Esses resultados revelaram a necessidade da mudança do fator de conversão para determinação do VG em cães de 2,94 para 3,54.

Palavras-chave: Cão, hemoglobina, hemoglobinômetro, volume globular

\section{Introduction}

The primary function of erythrocytes (also known as red blood cells), which are the most numerous blood cells, is to carry $\mathrm{Hb}$ (hemoglobin), which carries $\mathrm{O}_{2}$ from the lungs to the tissues and $\mathrm{CO}_{2}$ from the tissues to the lungs. Therefore, blood oxygenation depends on the number of circulating red blood cells, the packed cell volume (PCV or hematocrit), and the amount of $\mathrm{Hb}$. Anemia is a condition in which the number of erythrocytes, concentration of $\mathrm{Hb}$ and/or PCV values fall below the normal reference values. Anemic animals exhibit a number of clinical symptoms and physiological adjustments that result from the blood's reduced ability to carry $\mathrm{O}_{2}$ and/or the reduced circulating red blood cell mass (PEREIRA; RAMALHO, 2001). Thus, monitoring these values in animals is of great importance to detect and eliminate candidates with anemia during the selection of blood donors. Furthermore, monitoring these values is useful during clinical and surgical routines to assess anemia in cases of required blood transfusions and to follow up with patients after transfusions (CANÇADO; CHIATTONE; LANGHI, 2001).

Estimates of $\mathrm{Hb}$ and $\mathrm{PCV}$ concentrations can be performed by various methods. Currently, one of the most widely used methods for measuring $\mathrm{Hb}$ levels is a photometric technique based on the detection of cyanmethemoglobin (ROSENBLIT et al., 1999). As an alternative to this technology, another photometric method, which measures $\mathrm{Hb}$ concentrations based on the determination of azide methemoglobin, has been developed. This newer method consists of a portable photometer and individual microcuvettes that are filled with dry reagents. A small blood sample is taken up by capillary action into a disposable microcuvette, which is inserted into the equipment. The reagents present within the microcuvette lyse the red blood cells and convert the resulting free $\mathrm{Hb}$ into azide methemoglobin, which is then measured photometrically (ROSENBLIT et al., 1999).

This method has become increasingly widespread because it is simple, requires small blood samples, provides results more quickly and cheaper than traditional methods and because the required equipment can be used in outpatient settings, in the field and at ambulatory care clinics. The equipment is lightweight, easy to operate and handle, does not require refrigeration or constant access to electricity and provides immediate digitized results (MARIATH et al., 2006).

This study aimed to evaluate the performance of a portable hemoglobinometer Hemo_Vet (EKFDiagnostic), in measuring $\mathrm{Hb}$ concentrations and estimating $\mathrm{PCV}$ values in dogs. $\mathrm{Hb}$ and $\mathrm{PVC}$ values provided by the hemoglobinometer were compared with values determined by either the 
BC2800VET (an automated hematology analyzer) or the centrifugation technique of measuring microhematocrit using a micro centrifuge.

\section{Materials and Methods}

\section{Location}

This research was conducted at the Veterinary Clinic Department, Blood Bank (Project Life), Veterinary Hospital and Laboratory of Clinical Pathology of Universidade Estadual de Londrina (UEL), Londrina, Parana, Brazil. It was approved by the Committee of Ethics in the use of animals (CEUA) of UEL, the process number registered in CEUA/UEL is $13 / 11$.

\section{Samples}

A total of 140 tests were performed on a total of 100 blood samples from dogs treated at the UEL Veterinary Hospital and Project Life. The blood samples were originally from the Laboratory of Clinical Pathology of UEL and had been sent for complete blood counts. The samples consisted of venous blood from healthy dogs (blood donors) or from dogs with a variety of diseases and degrees of anemia. Samples were stored in EDTA tubes in a refrigerator for less than 24 hours prior to analysis as recommended by the Hemo_Vet Operator's Manual (EKF-Diagnostic).

\section{Groups}

The samples were divided into the following four groups:

Group1 (G1): Hb above 12g/dL (25samples);

Group 2 (G2): Hb between 11.90 and 9 g/dL (25 samples);

Group 3 (G3): Hb between 8.90 and $5 \mathrm{~g} / \mathrm{dL}$ (25 samples);
Group 4 (G4): $\mathrm{Hb}$ between 4.90 and $1 \mathrm{~g} / \mathrm{dL}$ (25 samples).

\section{Laboratory tests}

The work was divided into the following two phases:

- Phase one: PCV values that were obtained using the hemoglobinometer were compared with those obtained using the BC2800VET and with those obtained using the micro centrifuge method. As such, $\mathrm{Hb}$ values that were obtained using the hemoglobinometer were compared with those obtained using the BC2800VET, in order to determine agreement between these methods. This evaluation was performed in 100 samples.

- Phase two: Evaluations of the hemoglobinometer's imprecision in obtaining PCV and $\mathrm{Hb}$ values were performed for 10 repetitions of a single blood sample from each group described.

Measurements were taken according to the protocols found in the Hemo_Vet Operator's Manual (EKF-Diagnostic). Briefly, sample tubes were taken out of the refrigerator and placed in a blood mixer at room temperature to warm. A $10 \mu \mathrm{L}$ aliquot of blood was pipetted into the cavity of the cuvette. Care was taken to fill the cuvette completely without introducing air bubbles. The filled cuvette is then inserted into the equipment, the color that is produced by the chemical reaction in the cuvette is measured, and the $\mathrm{Hb}$ level is displayed once the cuvette had been filled, measurements were performed immediately. The Hemo_Vet has a wide measuring range ( 0 to $25.60 \mathrm{~g} / \mathrm{dl}$ ), and it provides $\mathrm{Hb}$ values within seconds. PCV values can be estimated from the measured $\mathrm{Hb}$ concentrations (at least those between $5.50-18 \mathrm{~g} / \mathrm{dL}$ ) by multiplying the $\mathrm{Hb}$ concentration by a factor of 2.94 , as stated in the Hemo_Vet Operator's Manual. (Figures 1 and 2). 
Figure 1. (A) A Hemo_Vet portable hemoglobinometer; (B) A microcuvette required for assessments; (C) A filled cuvette being inserted into the hemoglobinometer. Londrina - 2013.

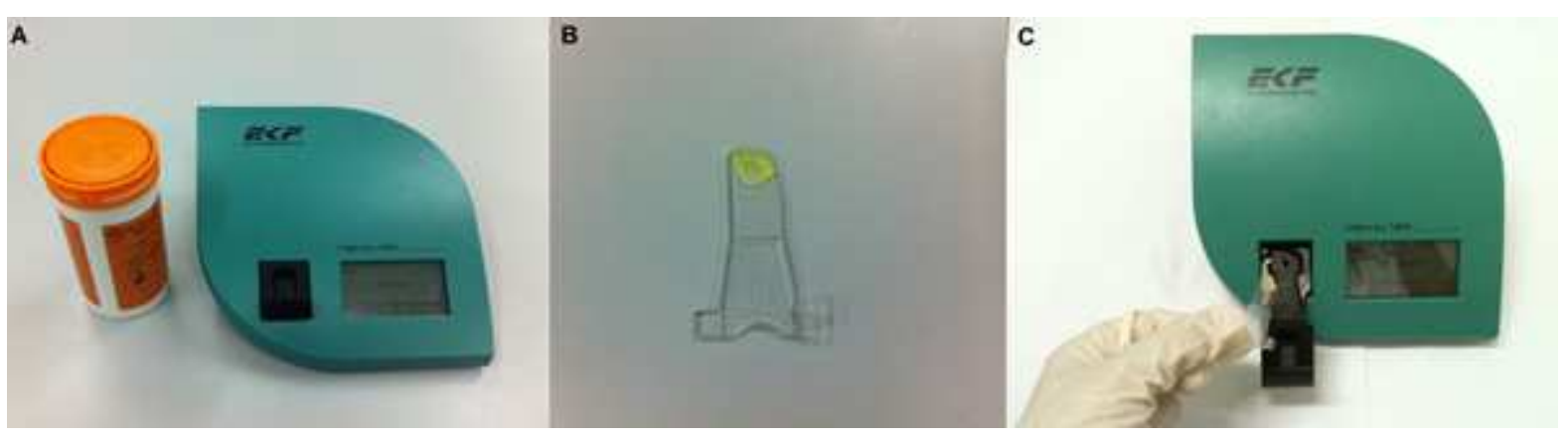

Source: Elaboration of the authors.

Figure 2. (A) Measurement; (B) Values are shown in the display. Londrina -2013.
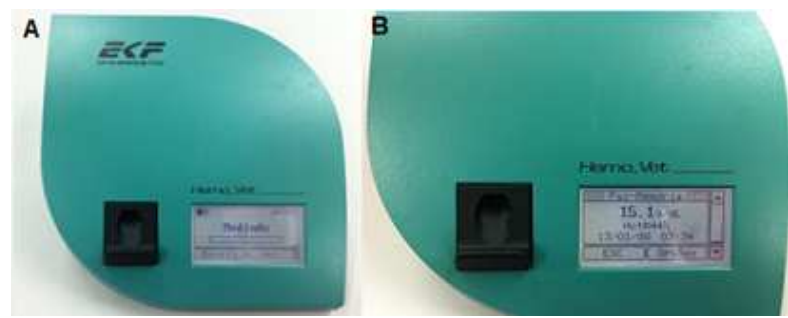

Source: Elaboration of the authors.

The BC2800VET is an automated hematology analyzer that uses electrical impedance for cell counting and a cyanide-free method to measure $\mathrm{Hb}$ levels. This apparatus requires $13 \mu \mathrm{L}$ samples of blood and can perform measurements at a rate of 30 samples per hour.

The third method used to evaluate PCV was the microhematocrit technique. In this technique, a capillary microtube is filled to $3 / 4$ of its height with a blood sample, one end is then occluded and the microtube is then placed into a micro centrifuge and centrifuged at a speed of $14.970 \mathrm{xg}$ for 5 minutes.

\section{Statistical analysis}

In the first phase, the Bland-Altman method was used to compare data obtained from the different devices using Analyse-it software. A significance level of $5 \%$ was adopted. The mean $(\bar{x})$, standard deviation (SD) and Pearson correlation coefficient $\left(\mathrm{r}^{2}\right)$ were calculated using Microsoft Office Excel ${ }^{\circledR}$ 2007.
During the second phase, the coefficient of variation $(\mathrm{CV}=100 *(\mathrm{SD} / \bar{x}))$ was utilized to assess imprecision. To define the acceptable difference between the methods, the following formula was used: $0 \pm 1.96^{*} \mathrm{CV}_{\text {total }} *$ mean of the measurements (where $\mathrm{CV}_{\text {total }}=\sqrt{\mathrm{CV}^{2}}$ method 1 $_{1}+\mathrm{CV}_{\text {method 2 }}^{2}$ ), as described by Jensen e Kjelgaard-Hansen (2006).

\section{Results}

The $\bar{x}, \mathrm{SD}$ and $\mathrm{r}^{2}$ were calculated to verify the correlations between the results obtained with the two devices. Bland-Altman analysis was used to evaluate correlations between two variables (X and $\mathrm{Y}$ ) from scatter plots that show the difference between the two variables $(\mathrm{X}-\mathrm{Y})$ and their means $(\mathrm{X}+\mathrm{Y}) / 2$. These charts reveal bias (average difference between the variables, should ideally be zero) and error (the dispersion of difference values around the mean). It is also possible to establish a limit of agreement (within a given confidence 
interval) between the two methods tested (JENSEN; KJELGAARD-HANSEN, 2006).

A comparison of the $\mathrm{Hb}$ values obtained using the BC2800VET with those obtained using the hemoglobinometer and the data presented in Table 1 revealed a strong correlation between the results, with a correlation coefficient of $0.9928(95 \%$ $\mathrm{CI}=[0.9889 ; 0.9953])(\mathrm{COHEN}, 1988)($ Figure 3).

Table 1. The arithmetic mean $(\bar{x})$ and standard deviation (SD) of the Hb results obtained using the BC2800VET and the hemoglobinometer in different groups.

\begin{tabular}{cccc}
\hline Groups & & Hb (g/dl) BC2800VET & Hb (g/dl) Hemoglobinometer \\
\hline & $\bar{x}$ & 14.79 & 14.60 \\
$\mathbf{1}$ & $\mathrm{SD}$ & 2.30 & 2.36 \\
\hline \multirow{2}{*}{$\mathbf{x}$} & $\bar{x}$ & 10.37 & 10.10 \\
$\mathbf{3}$ & $\mathrm{SD}$ & 0.90 & 1.08 \\
\hline & $\bar{x}$ & 7.64 & 7.37 \\
$\mathbf{4}$ & $\mathrm{SD}$ & 1.11 & 1.14 \\
\hline & $\bar{x}$ & 3.63 & 3.66 \\
& $\mathrm{SD}$ & 0.65 & 0.74 \\
\hline
\end{tabular}

Source: Elaboration of the authors.

Figure 3. Correlations between the $\mathrm{Hb}$ values $(\mathrm{g} / \mathrm{dl})$ obtained using the $\mathrm{BC} 2800 \mathrm{VET}$ and the hemoglobinometer. $r=0.9928$. Londrina -2013 .

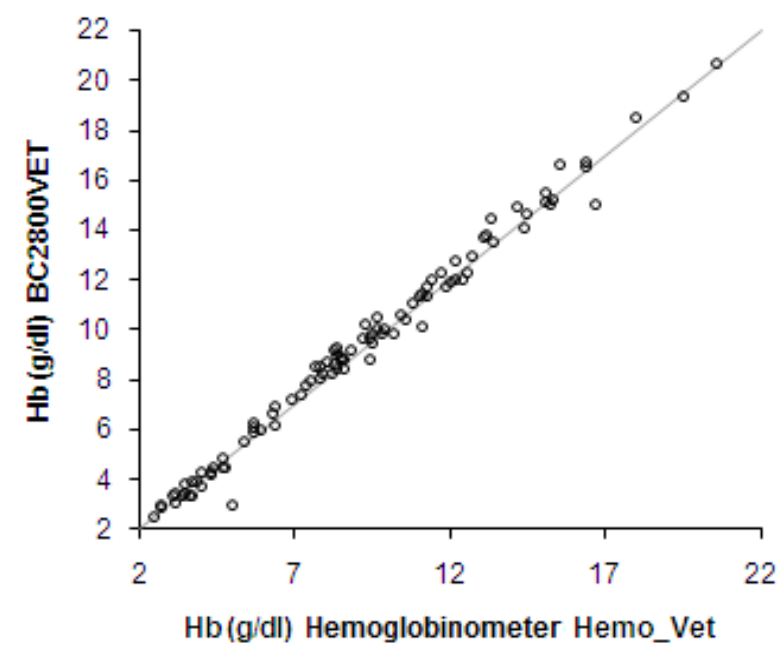

Source: Elaboration of the authors.

No differences were observed among the groups when assessing the groups separately. All $\mathrm{Hb}$ results are presented in a single Bland-Altman graph, where is possible to observe that the bias is 0.17 (i.e., very close to zero). Despite being statistically significant $(p=0.0003)$, this result has no clinical significance (Figure 4). In addition, 95\% of the samples are within the limits of agreement, with a maximum difference between the two $\mathrm{Hb}$ measurements of $1.08 \mathrm{~g} / \mathrm{dl}$. 
Figure 4. A Bland-Altman graph of the differences (y-axis) and means (x-axis) between the Hb valuesobtained using the $\mathrm{BC} 2800 \mathrm{VET}$ and the hemoglobinometer. Bias $=0.17$, upper limit of agreement.

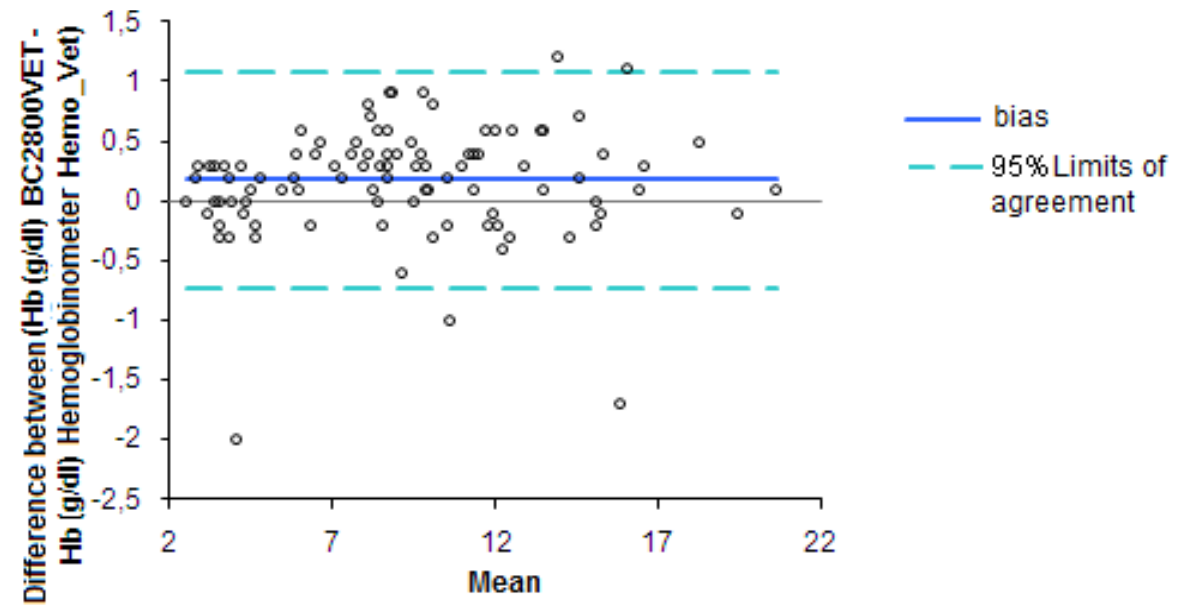

Source: Elaboration of the authors.

The agreement between the following G3 because the PCV values in G4 were all lower methods of PCV estimation was evaluated: than $18 \%$, which is below the threshold where the 1- hemoglobinometer and BC2800VET; 2- hemoglobinometer was verified effective when hemoglobinometer and the microhematocrit using the microhematocrit technique as a reference. technique; 3- BC2800VET and the microhematocrit In addition, the hemoglobinometer was not able technique. Agreement was measured using Bland- to determine values above $59 \%$, which resulted in Altman analysis, and correlations were assessed the exclusion of two samples from G1. Therefore, using the $\mathrm{r}^{2}$. The $\bar{x}$ and SD were also calculated. a total of 73 samples were evaluated. Statistical The described tests were applied only in G1, G2 and calculations of the three methods examined are presented in Table 2.

Table 2. The arithmetic mean $(\bar{x})$ and standard deviation (SD) of PCV values obtained using the BC2800VET or the techniques using the microhematocrit and the hemoglobinometer in the different groups.

\begin{tabular}{ccccc}
\hline Groups & & PCV\% BC2800VET & PCV\% microhematocrit & PCV\% Hemoglobinometer \\
\hline \multirow{2}{*}{$\mathbf{1}$} & $\overline{\boldsymbol{x}}$ & 51.67 & 43.83 & 41.52 \\
$\mathbf{2}$ & $\mathrm{SD}$ & 6.68 & 5.57 & 5.23 \\
\hline \multirow{2}{*}{$\mathbf{3}$} & $\bar{x}$ & 37.54 & 32.92 & 29.80 \\
& $\mathrm{SD}$ & 3.63 & 3.77 & 3.16 \\
\hline & $\bar{x}$ & 27.43 & 24.72 & 21.96 \\
$\mathbf{4}$ & $\mathrm{SD}$ & 3.58 & 3.26 & 3.16 \\
\hline
\end{tabular}

Source: Elaboration of the authors. 
A comparison of the results obtained using the hemoglobinometer with those using the microhematocrit technique revealed that the PCV differences between these techniques are greater than differences observed for $\mathrm{Hb}$. Nonetheless, a strong correlation was observed $\left(r^{2}=0.9754,95 \%\right.$ $\mathrm{CI}=[0.9608,0.9846])$, as shown in Figure 5.

Examining both method with Bland-Altman analysis (Figure 6) revealed a bias of 2.80, which was statistically significant $(p<0.0001)$. Agreement limits indicate that $6.70 \%$ is the maximum difference that is likely to be observed between the two PCV measurement methods in 95\% of the samples. This difference may have clinical significance. For example, in a selection of dogs to be blood donors, if a dog's PCV is determined to be $34 \%$ (which is below the reference value), it would not be selected as a blood donor. However, if an error of $6 \%$ occurs during the determination of PCV, a dog with an apparent PCV of $40 \%$ could be improperly selected as a donor.

Comparing the PCV values determined using the hemoglobinometer and BC2800VET methods revealed a strong bias (7.85) that is likely to have clinically significant implications, even despite the significant correlation observed $\left(\mathrm{r}^{2}=0.9533,95 \%\right.$ $\mathrm{CI}=[0.9262,0.9706])($ Figure 7$)$.

The Bland-Altman graph demonstrates a bias of $7.85(\mathrm{p}<0.0001)$ and a limit of agreement as high as 14.90, as shown in Figure 8.

To evaluate the imprecision of the Hemo_Vet, 10 repetitions of the same sample were performed in each group. The results from this precision analysis are presented in Table 3.

Figure 5. The correlation between the PCV values obtained using the microhematocrit technique and those obtained using the hemoglobinometer. $\mathrm{r}=0.9754$. Londrina -2013 .

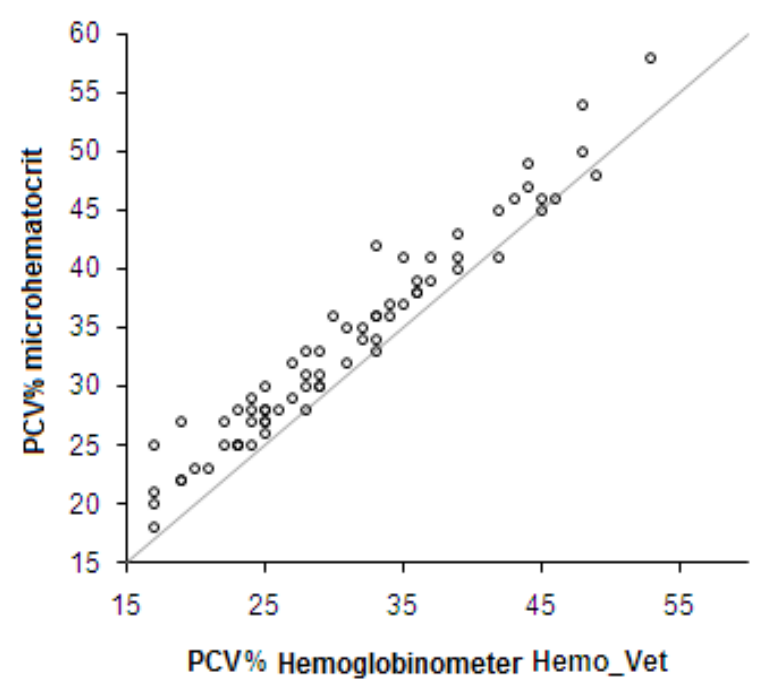

Source: Elaboration of the authors. 
Figure 6. A Bland-Altman graph showing the differences (y-axis) and means (x-axis) between the PCV values obtained using the microhematocrit and hemoglobinometer techniques. Bias $=2.80$; upper limit of agreement $=6.70$; lower limit of agreement $=-1.00$. Londrina -2013 .

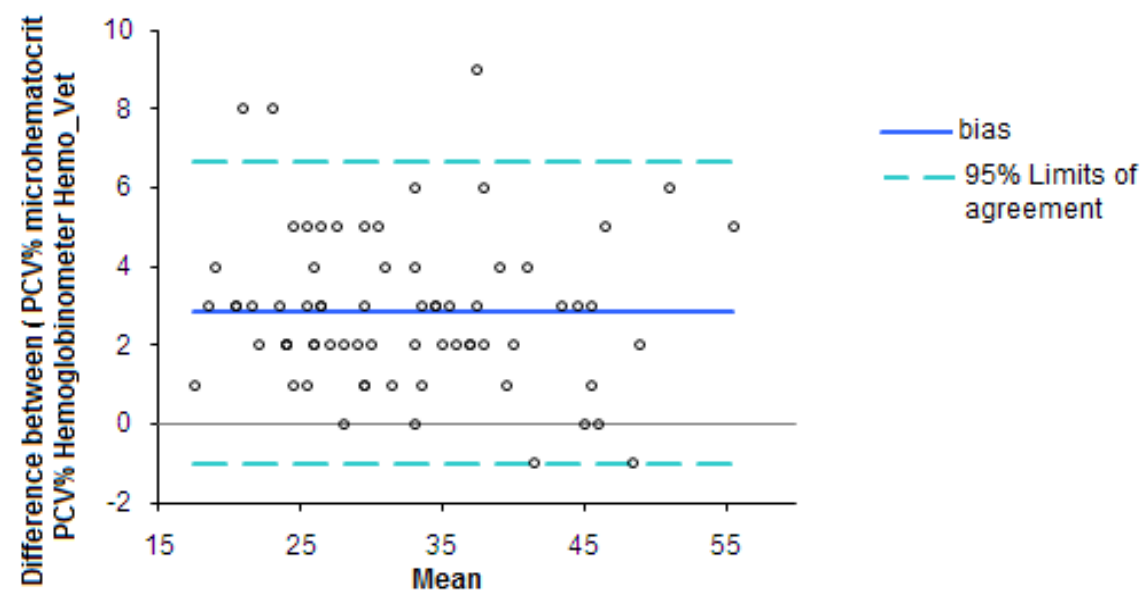

Source: Elaboration of the authors.

Figure 7. The correlation between the PCV values obtained using the BC2800VET with those obtained using the hemoglobinometer. $r=0.9533$. Londrina -2013 .

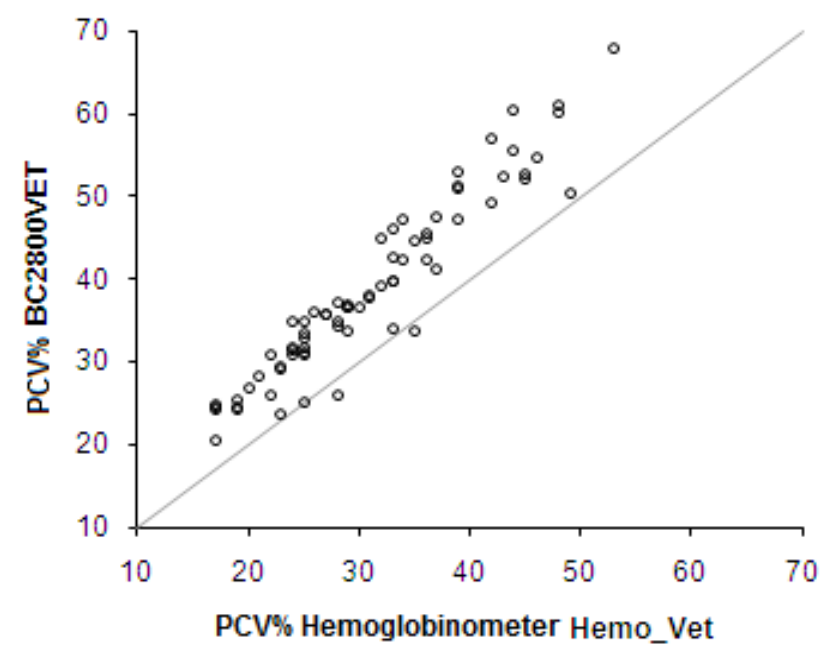

Source: Elaboration of the authors. 
Figure 8. A Bland-Altman graph of differences (y-axis) and means (x-axis) between the PCV values obtained using the $\mathrm{BC} 2800 \mathrm{VET}$ and those obtained using the hemoglobinometer. Bias $=7.85$; upper limit of agreement $=14.90$; lower limit of agreement $=0.8$. Londrina -2013 .

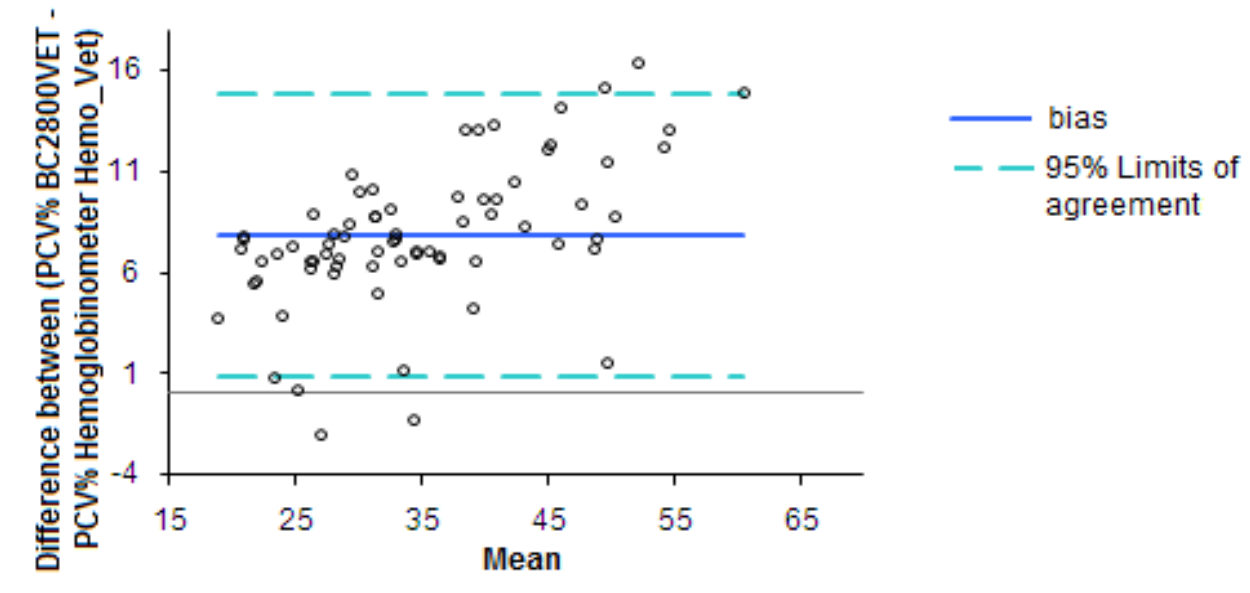

Source: Elaboration of the authors.

Table 3. Arithmetic mean $(\bar{x})$, standard deviation (SD) and coefficient of variation $(\mathrm{CV})$ of $\mathrm{Hb}$ and PCV results obtained to evaluate the imprecision of hemoglobinometer.

\begin{tabular}{ccccccccc}
\hline & \multicolumn{2}{c}{ Group 1 } & \multicolumn{2}{c}{ Group 2 } & \multicolumn{2}{c}{ Group 3 } & \multicolumn{2}{c}{ Group 4 } \\
\hline $\begin{array}{c}\text { Number of } \\
\text { Evaluations }\end{array}$ & $\begin{array}{c}\text { Hb (g/ } \\
\mathbf{d l})\end{array}$ & $\mathbf{P C V} \%$ & $\begin{array}{c}\text { Hb (g/ } \\
\mathbf{d l})\end{array}$ & $\mathbf{P C V \%}$ & $\begin{array}{c}\text { Hb (g/ } \\
\mathbf{d l})\end{array}$ & $\mathbf{P C V \%}$ & $\begin{array}{c}\text { Hb (g/ } \\
\mathbf{d l})\end{array}$ & $\mathbf{P C V \%}$ \\
\hline 01 & 16.70 & 49.00 & 11.10 & 33.00 & 9.40 & 28.00 & 3.10 & N/A \\
02 & 16.70 & 49.00 & 11.00 & 32.00 & 9.60 & 28.00 & 3.40 & N/A \\
03 & 16.80 & 49.00 & 11.00 & 32.00 & 9.60 & 28.00 & 3.20 & N/A \\
04 & 16.90 & 50.00 & 11.10 & 33.00 & 9.60 & 28.00 & 3.20 & N/A \\
05 & 16.80 & 49.00 & 11.10 & 33.00 & 9.40 & 28.00 & 3.30 & N/A \\
06 & 16.80 & 49.00 & 11.10 & 33.00 & 9.40 & 28.00 & 3.20 & N/A \\
07 & 17.20 & 51.00 & 11.20 & 33.00 & 9.30 & 27.00 & 3.20 & N/A \\
08 & 16.80 & 49.00 & 11.20 & 33.00 & 9.30 & 27.00 & 3.30 & N/A \\
09 & 16.90 & 50.00 & 11.30 & 33.00 & 9.60 & 28.00 & 3.30 & N/A \\
10 & 17.00 & 50.00 & 11.50 & 34.00 & 9.40 & 28.00 & 3.20 & N/A \\
\hline $\bar{x}$ & 16.86 & 49.50 & 11.16 & 32.90 & 9.46 & 27.80 & 3.24 & - \\
SD & 0.15 & 0.71 & 0.15 & 0.57 & 0.13 & 0.42 & 0.08 & - \\
CV\% & 0.88 & 1.43 & 1.34 & 1.73 & 1.37 & 1.51 & 2.46 & - \\
\hline
\end{tabular}

$\mathrm{N} / \mathrm{A}=$ result not available.

Source: Elaboration of the authors.

\section{Discussion}

The performance of the Hemo_Vet was shown to be better for measuring $\mathrm{Hb}$ levels than for estimating PCV, with a maximum difference of 1.08 $\mathrm{g} / \mathrm{dl}$ in determining $\mathrm{Hb}$. The PCV results obtained using the Hemo_Vet were more similar to those obtained using centrifugation in a micro centrifuge than to those obtained using the BC2800VET. This can be explained by the fact that the BC2800VET device determines the PCV values using a formula that takes the number of red blood cells into account $\left(\mathrm{MCV}=\mathrm{PCV} / \mathrm{RBC}^{*} 10^{6}\right.$, where $\mathrm{MCV}$ 
$=$ mean corpuscular volume, $\mathrm{PCV}=$ packed cell volume and $\mathrm{RBC}=$ red blood cells), as stated in the manufacturer's manual. Therefore, the BC2800VET should not be considered to be a direct measure of PCV values because it presents significant alterations in PCV values from those obtained using the microhematocrit technique, which is currently the most widely accepted method.

The SD and CV obtained during analysis of imprecision indicated that the Hemo_Vet exhibits only small variations between repetitions. The precision achieved by this device should be considered good based on the recommendation that $\mathrm{CV}$ values should be less than 5\% for automated testing and below $10 \%$ for manual testing, as proposed by Jensen e Kjelgaard-Hansen (2010).

The results of the current study demonstrate that the Hemo_Vet portable hemoglobinometer fulfills its primary purpose, which is to measure $\mathrm{Hb}$ levels precisely and accurately. Indeed, the small variations observed compared to the reference method were not likely to be clinically relevant. Based on the acceptable difference calculated between the two methods for the $\mathrm{Hb}$ values, the present results suggest that these methods can be used interchangeably because the mean difference between the $\mathrm{Hb}$ values obtained by both methods is within the interval $0 \pm$ $1.54 \mathrm{~g} / \mathrm{dl}$. A study with human blood donors showed a similar result, the mean difference between the $\mathrm{Hb}$ values obtained by the hemoglobinometer tested and an automated hematology analyzer was very close to zero (KIM et al., 2013). These results are different from those found in another report of a portable hemoglobinometer, in which the findings "were systematically biased and too unreliable", according to Gayat et al. (2011).

In contrast, the Hemo_Vet hemoglobinometer was not very effective in determining PCV values, which were characterized by large variations with the methods used for comparison. For methods to be appropriate they should exhibit a bias close to zero and an error within the interval of the acceptable difference calculated. In addition, any variations in the accuracy or precision of the instrument should not be large enough to have a significant clinical impact, and different methods should be able to be used interchangeably, similar to what was observed for $\mathrm{Hb}$ measurements. However, the mean difference between the PCV values obtained by the Hemo_Vet hemoglobinometer and the BC2800VET and those observed between the hemoglobinometer and the microhematocrit technique were not within the ranges calculated using the formula of acceptable difference, which were $0 \pm 2.87 \mathrm{~g} / \mathrm{dl}$ and $0 \pm 1.18$ $\mathrm{g} / \mathrm{dl}$, respectively. Based on these results, after the performance of this study, the manufacturer identified the need to change the conversion factor for determining PCV values from 2.94 to 3.54 for dogs. Posner, Erb and Gleed (2005) evaluated a hemoglobinometer and also could found a conversion factor of 3.10 for cats.

It is important to highlight that the Hemo_Vet was not able to determine PCV values below $18 \%$ and above $59 \%$ using the microhematocrit technique as reference. A greater interval was observed by Lysa Hollis and Robin (2005) in a study with cats: $3 \%-$ $79 \%$. The manufacturer's manual claims that PCV values can be estimated from $\mathrm{Hb}$ concentrations between 5.5 and $18 \mathrm{~g} / \mathrm{dl}$, which is consistent with the results of this study. However, the Hemo_Vet was not as effective for PCV determinations because of its lack of consistency with the other methods of comparison. This discrepancy highlighted the need to change the conversion factor for estimating PCV values from 2.94 to 3.54 for dogs.

As a practical and portable method that requires a minimal amount of blood $(8 \mu \mathrm{L})$, the use of the Hemo_Vet in veterinary medicine is indicated in emergency situations, the screening of blood donors, assessing the need for blood transfusions and in monitoring anemic patients, at least when it is used exclusively to measure $\mathrm{Hb}$ values. 


\section{Acknowledgements}

We acknowledge EKF-Diagnostic and VJR Commercial for providing the portable Hemo_Vet hemoglobinometer (EKF-Diagnostic) and the microcuvettes. We are also grateful to the members of the Blood Bank (Project Life, UEL, Parana, Brazil) for their help in material collection and to the Veterinary Clinic Department, Veterinary Hospital and Laboratory of Clinical Pathology, UEL, Parana, Brazil, for technical support.

\section{References}

CANÇADO, R. D.; CHIATTONE, C. S.; LANGHI, D. M. Deficiência de ferro em doadores de sangue (Iron deficiency in blood donors). Revista Brasileira de Hematologia e Hemoterapia, São José do Rio Preto, v. 23, n. 2, p. 108-109, 2001.

COHEN, J. Statistical power analysis for the behavioral sciences. $2^{\text {nd }}$ ed. Hillsdale: Erlbaum, 1988.

GAYAT, E.; BODIN, A.; SPORTIELLO, C.; BOISSON, M.; DREYFUS, J. F.; MATHIEU, E.; FISCHLER, M. Performance evaluation of a noninvasive hemoglobin monitoring device. Annals of Emergency Medicine, Suresnes, France, v. 57, n. 4, p. 330-333, 2011.

JENSEN, A. L.; KJELGAARD-HANSEN, M. Diagnostic test validation. In: WEISS, D.; WARDROP, K. J. Schalm's veterinary hematology. $6^{\text {th }}$ ed. EUA: Blackweel, p. 1027-1033, 2010.

Method comparison in the clinical laboratory. Veterinary Clinical Pathology, Madison, v. 35, n. 3, p. 276-286, 2006.
KIM, M. J.; PARK, Q.; KIM, M. H.; SHIN, J. W.; KIM, A. H. O. Comparison of the Accuracy of noninvasive hemoglobin sensor (NBM-200) and portable hemoglobinometer (HemoCue) with an Automated hematology analyzer (LH500) in blood donor screening. Annals of Laboratory Medicine, Gwacheon, v. 33, n. 4, p. 261-267, 2013.

LYSA, P. P.; HOLliS, N. E.; ROBIN, D. G. The HemoCue ${ }^{\circledR}$ for point of care hemoglobin measurement and packed cell volume estimation in cats. Journal of Veterinary Emergency and Critical Care, v. 15, n. 1, p. 22-25, 2005.

MARIATH, A. B.; HENN, R.; MATOS, C. H.; LACERDA, L. L. V.; GRILLO, L. P. Prevalência de anemia e níveis séricos de hemoglobina em adolescentes segundo estágio de maturidade sexual (Prevalence of anemia and hemoglobin serum levels in adolescents according to sexual maturation stage). Revista Brasileira de Epidemiologia, Balneário Camboriú, v. 9, n. 4, p. 454461, 2006.

PEREIRA, P. M.; RAMALHO, F. S. Transfusão sanguínea (Blood transfusion). Revista Clínica Veterinária, Londrina, v. 6, n. 34, p. 34-40, 2001.

POSNER, L. P.; ERB, H. N.; GLEED, R. D. The HemoCue ${ }^{\circledR}$ for point of care hemoglobin measurement and packed cell volume estimation in cats. Journal of Veterinary Emergency and Critical Care, Ithaca, v. 15, n. 1, p. 22-25, 2005.

ROSENBLIT, J.; ABREU, C. R.; SZTERLING, L. N.; KUTNER, J. M.; HAMERSCHLAK, N.; FRUTUOSO, P.; PAIVA, T. R. S. S.; FERREIRA JÚNIOR, O. C. Evaluation of three methods for hemoglobin measurement in a blood donor setting. São Paulo Medical Journal, São Paulo, v. 117, n. 3, p. 108-112, 1999. 
